\title{
SCIENTIFIC OPINION
}

\section{Statement on further elaboration of the consumption figure of $400 \mathrm{~g}$ shellfish meat on the basis of new consumption data ${ }^{1}$}

\author{
EFSA Panel on Contaminants in the Food Chain (CONTAM) $)^{2,3}$
}

European Food Safety Authority (EFSA), Parma, Italy

\begin{abstract}
The EFSA Panel on Contaminants in the Food Chain (CONTAM Panel) has prepared a series of opinions since 2007 on various marine biotoxins, including emerging toxins, to assess the current European Union (EU) limits with regard to human health and methods of analysis as established in the EU legislation. In order to protect high consumers against acute effects of marine biotoxins, the CONTAM Panel identified $400 \mathrm{~g}$ of shellfish meat as an appropriate estimate of a large portion size consumed in Europe to be used in the risk assessments. This portion size was then applied to all the scientific opinions on marine biotoxins. Recently EFSA has received new data from Belgium, France, Portugal and Spain on the shellfish portion sizes consumed. In addition, new consumption data have been submitted to EFSA for inclusion in the Comprehensive European food consumption database (Comprehensive Database). Based on the assessment of the new data provided to EFSA and the information included in the EFSA Comprehensive Database, the CONTAM Panel concluded that the earlier established estimate of the consumption figure of $400 \mathrm{~g}$ shellfish meat is appropriate for protecting high consumers against acute effects of marine biotoxins.
\end{abstract}

\section{KEY WORDS}

Marine biotoxins, shellfish, consumption, large portion size, human health, risk assessment

1 On request from the European Commission, Question No EFSA-Q-2010-00155, adopted on 31 July 2010.

2 Panel members: Jan Alexander, Diane Benford, Alan Boobis, Sandra Ceccatelli, Jean-Pierre Cravedi, Alessandro Di Domenico, Daniel Doerge, Eugenia Dogliotti, Lutz Edler, Peter Farmer, Metka Filipič, Johanna Fink-Gremmels, Peter Fürst, Thierry Guérin, Helle Katrine Knutsen, Miroslav Machala, Antonio Mutti, Josef Schlatter and Rolaf van Leeuwen. Correspondence: contam@efsa.europa.eu

3 Acknowledgement: The Panel wishes to thank the members of the Working Group on marine biotoxins for the preparation of this opinion: Jan Alexander, Diane Benford, Luis Botana, Peter Fürst, Gerhard Heinemeyer, Philipp Hess, Angelika Preiss-Weigert, Hans van Egmond and Rolaf van Leeuwen and EFSA's staff members Mari Eskola, Jean-Lou Dorne, Francesco Vernazza and Davide Arcella for the support provided to this EFSA scientific output.

Suggested citation: EFSA Panel on Contaminants in the Food Chain (CONTAM); Statement on further elaboration of the consumption figure of $400 \mathrm{~g}$ shellfish meat on the basis of new consumption data. EFSA Journal 2010; 8(8):1706. [20 pp.]. doi:10.2903/j.efsa.2010.1706. Available online: www.efsa.europa.eu 


\section{SUMMARY}

In July 2006 the European Commission (EC) requested the European Food Safety Authority (EFSA) to provide a scientific opinion to assess the current European Union (EU) limits with regard to human health and methods of analysis for various marine biotoxins as established in the EU legislation, including new emerging toxins.

In response, EFSA's Panel on Contaminants in the Food Chain (CONTAM Panel) has developed and adopted a series of scientific opinions related to marine biotoxins: okadaic acid (OA) and analogues, azaspiracid (AZA)-group toxins, yessotoxin (YTX)-group toxins, saxitoxin (STX)-group toxins, pectenotoxin (PTX)-group toxins, domoic acid (DA), palytoxin (PITX)-group toxins, ciguatoxin (CTX)-group toxins, cyclic imines (CIs) and brevetoxin (BTX)-group toxins. In addition, a statement on the influence of processing on the levels of lipophilic marine biotoxins in bivalve molluscs and a summary opinion on the currently regulated marine biotoxins have been issued.

At the time of writing of the first opinion, consumption data on shellfish types across the EU were limited and therefore EFSA requested member states (MSs) to provide information on consumption of relevant shellfish types. Based on the data provided by five MSs, the CONTAM Panel identified $400 \mathrm{~g}$ of shellfish meat as an appropriate estimate of a large portion size consumed in Europe to be used in its risk assessments in order to protect high consumers against acute effects of marine biotoxins. This portion size was then applied to all other scientific opinions on marine biotoxins. Recently EC has received new data from Belgium, France, Portugal and Spain on the shellfish portion sizes consumed and therefore asked EFSA to assess the new consumption data submitted by the MSs on shellfish portion size in order to evaluate whether the CONTAM Panel's established estimate of the consumption figure of $400 \mathrm{~g}$ shellfish meat is appropriate for protecting high consumers against acute effects of marine biotoxins. The CONTAM Panel considered these new data and also the data present now in the EFSA Comprehensive European food consumption database (Comprehensive Database).

Based on the information present in the EFSA Comprehensive Database, the CONTAM Panel estimated that the proportions of consuming days exceeding $100 \mathrm{~g}$ shellfish were $0.5-3 \%$ (Spain), $9 \%$ (Ireland), $13 \%$ (Italy), $14 \%$ (Finland), $18 \%$ (Germany), $19 \%$ (UK), $24 \%$ (France) and $48 \%$ (Belgium), while the proportions of consuming days exceeding $200 \mathrm{~g}$ shellfish were $2 \%$ (Italy), $2.5 \%$ (France), $4 \%$ (Ireland), $7 \%$ (UK), $11 \%$ (Belgium) and $15 \%$ (Germany).

The CONTAM Panel considered the $95^{\text {th }}$ percentile as a realistic estimate of the large portion size to protect high consumers against acute effects of marine biotoxins in shellfish. Revised consumption data for "consumers only" submitted by France indicate a $95^{\text {th }}$ percentile of consumption of bivalve molluscs of $300 \mathrm{~g}$. This value supports the earlier established estimate of a large portion size of $400 \mathrm{~g}$ shellfish meat. Evaluation of the EFSA Comprehensive European food consumption database (Comprehensive Database) shows a highest $95^{\text {th }}$ percentile portion size for shellfish meat of $251 \mathrm{~g}$ with an upper confidence limit of $500 \mathrm{~g}$. Also these data do not warrant a revision of the earlier established estimate of a large portion size. Therefore the CONTAM Panel concluded that the earlier estimate of a large portion size of $400 \mathrm{~g}$ shellfish meat is appropriate for protecting high consumers against acute effects of marine biotoxins. 


\section{TABLE OF CONTENTS}

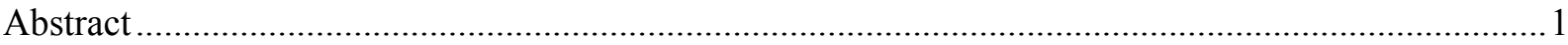

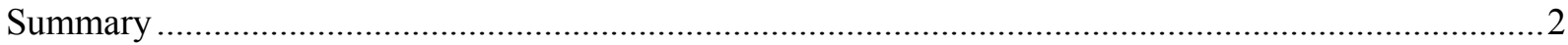

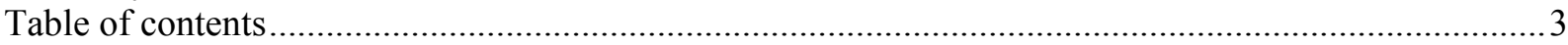

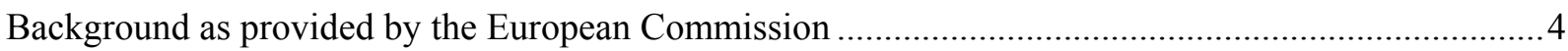

Terms of reference as provided by the European Commission ........................................................... 4

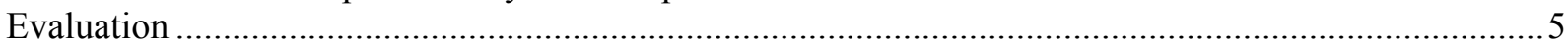

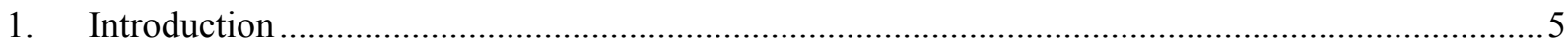

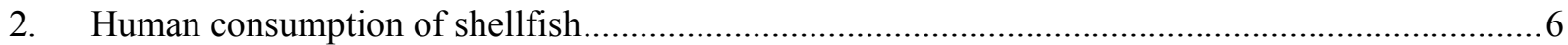

2.1. Consumption data submitted by member states to EFSA in 2007 and used in the adopted

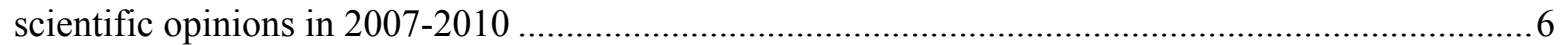

2.2. Consumption data submitted by Belgium, France, Portugal and Spain to EC/EFSA in 20097

2.3. Consumption data in EFSA Comprehensive Database......................................................... 8

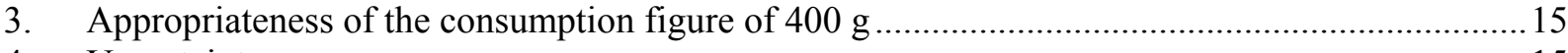

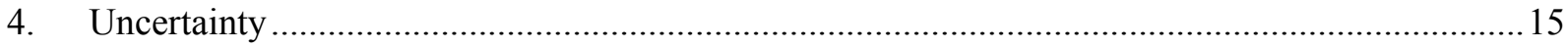

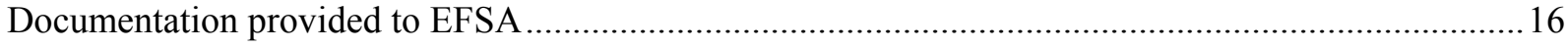

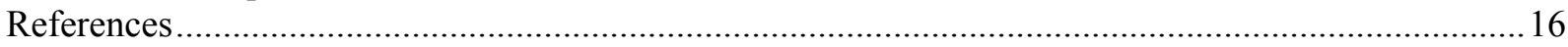

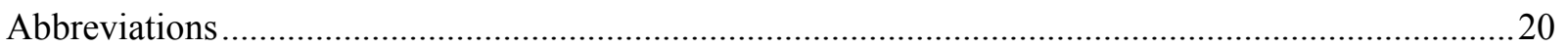




\section{BACKGROUND AS PROVIDED BY THE EUROPEAN COMMISSION}

Regulation (EC) No 853/2004 of the European Parliament and of the Council of 29 April 2004 laying down specific hygiene rules for food of animal origin ${ }^{4}$ establishes maximum levels for marine biotoxins in live bivalve molluscs.

Commission Regulation (EC) No $2074 / 2005^{5}$ of 5 December 2005 laying down implementing measures for certain products under Regulation (EC) No 853/2004 of the European Parliament and of the Council and for the organisation of official controls under Regulation (EC) No 854/2004 ${ }^{7}$ of the European Parliament and of the Council and Regulation (EC) No $882 / 2004^{8}$ of the European Parliament and of the Council, derogating from Regulation (EC) No $852 / 2004^{9}$ of the European Parliament and of the Council and amending Regulations (EC) No 853/2004 and (EC) No 854/2004 establishes the recognised testing methods for detecting marine biotoxins.

In July 2006 the Commission requested EFSA to provide a scientific opinion to assess the current European Union (EU) limits with regard to human health and methods of analysis for various marine biotoxins as established in the EU legislation, including new emerging toxins.

In response, EFSA's Panel on Contaminants in the Food Chain (CONTAM Panel) has adopted a series of scientific opinions related to marine biotoxins: okadaic acid (OA) and analogues, azaspiracid (AZA)-group toxins, yessotoxin (YTX)-group toxins, saxitoxin (STX)-group toxins, pectenotoxin (PTX)-group toxins, domoic acid (DA) and palytoxin (PITX)-group toxins. In addition a statement on the influence of processing on the levels of lipophilic marine biotoxins in bivalve molluscs and a summary opinion on the currently regulated toxins have been issued.

For its first scientific opinion on okadaic acid and analogues, the CONTAM Panel identified $400 \mathrm{~g}$ of shellfish meat as an appropriate estimate of a large portion size consumed in Europe in order to protect human health against acute effects of marine biotoxins. This portion size was then applied to all other scientific opinions on marine biotoxins.

Recently the European Commission has received new data from certain Member States on the shellfish portion sizes consumed and forwarded these data to EFSA.

\section{TERMS OF REFERENCE AS PROVIDED BY THE EUROPEAN COMMISSION}

In accordance with Art. 29 (1) (a) of Regulation (EC) No 178/2002, the European Commission asks EFSA to assess the new consumption data submitted by Member States on shellfish portion size in order to evaluate if the CONTAM Panel's established estimate on the consumption figure of $400 \mathrm{~g}$ shellfish meat is the appropriate estimate for protecting human health against acute effects of marine biotoxins. EFSA is asked to revise, if appropriate, its previous scientific opinions related to marine biotoxins.

\footnotetext{
${ }^{4}$ OJ L 226, 25.6.2004, p. 22-82.

${ }^{5}$ OJ L 338, 22.12.2005, p. 27-59.

${ }^{6}$ OJ L 139, 30.4.2004, p. 55-205.

${ }^{7}$ OJ L 139, 30.4.2004, p. 206-320.

${ }^{8}$ OJ L 165, 30.4.2004, p. 1-141.

${ }^{9}$ OJ L 139, 30.4.2004, p. 1-54.
} 


\section{EVALUATION}

\section{Introduction}

In July 2006 the European Commission (EC) requested the European Food Safety Authority (EFSA) to provide a scientific opinion to assess the current European Union (EU) limits with regard to human health and methods of analysis for various marine biotoxins as established in the EU legislation, including new emerging toxins.

In response, EFSA's Panel on Contaminants in the Food Chain (CONTAM Panel) has developed and adopted a series of scientific opinions related to marine biotoxins: okadaic acid (OA) and analogues (EFSA, 2008a), azaspiracid (AZA)-group toxins (EFSA, 2008b), yessotoxin (YTX)-group toxins (EFSA, 2008c), saxitoxin (STX)-group toxins (EFSA, 2009a), pectenotoxin (PTX)-group toxins (EFSA, 2009b), domoic acid (DA) (EFSA, 2009c), palytoxin (PITX)-group toxins (EFSA, 2009d), ciguatoxin (CTX)-group toxins (EFSA, 2010a), cyclic imines (CIs) (EFSA, 2010b) and brevetoxin (BTX)-group toxins (EFSA, 2010c). In addition, a statement on the influence of processing on the levels of lipophilic marine biotoxins in bivalve molluscs (EFSA, 2009e) and a summary opinion on the currently regulated marine biotoxins (EFSA, 2009f) have been issued.

At the time of writing of the first opinion (EFSA, 2008a), consumption data on shellfish types across the EU were limited and therefore EFSA requested member states (MSs) to provide information on consumption of relevant shellfish types. Based on the data provided by five MSs, the CONTAM Panel identified $400 \mathrm{~g}$ of shellfish meat as an appropriate estimate of a large portion size consumed in Europe to be used in its risk assessments in order to protect high consumers against acute effects of marine biotoxins. This portion size was then applied to all other scientific opinions on marine biotoxins. Recently EC has received new data from Belgium, France, Portugal and Spain on the portion sizes of consumed shellfish and therefore asked EFSA to assess the new consumption data submitted by the four MSs in order to evaluate if the CONTAM Panel's established estimate of the consumption figure of $400 \mathrm{~g}$ shellfish meat is appropriate for protecting human health against acute effects of marine biotoxins.

To enable detailed exposure assessment, EFSA has now developed a Comprehensive European food consumption database (Comprehensive Database) which replaces the previous EFSA Concise European food consumption database (Concise Database). ${ }^{10}$ The EFSA Comprehensive Database comprises food consumption data from 20 different MSs resulting from their most recent national dietary surveys on the adult population. The EFSA Comprehensive Database includes individual consumption figures at the eating occasion level. As of July 2010 this database has not yet been officially released and critical evaluation of the data is still ongoing. Nevertheless, preliminary statistics on consumption of single shellfish types are presented in this statement.

\footnotetext{
${ }^{10}$ The EFSA Concise European food consumption database (Concise Database), with data on average daily consumption of foods per person sourced in the adult population of 17 different member states, Iceland and Norway, has been fully operational since February 2008. It is the first European database with dietary information from the majority of European Union member states.
} 


\section{Human consumption of shellfish}

\subsection{Consumption data submitted by member states to EFSA in 2007 and used in the adopted scientific opinions in 2007-2010}

In all the adopted scientific opinions, the CONTAM Panel noted that limited consumption data were available for individual shellfish types across the EU and that the EFSA Concise European food consumption database ${ }^{10}$ did not provide sufficient information because there was no differentiation between meal sizes for fish and other seafood. Therefore, EFSA requested the MSs to provide information on shellfish consumption. Data were submitted by France, Germany, Italy, the Netherlands and the United Kingdom (UK) in 2007. A compilation of the data received is presented in Table 1.

The German national food consumption survey performed by a weighing protocol in the late 1980s indicated a mean portion size of $107 \mathrm{~g}$ and a $95^{\text {th }}$ percentile of $400 \mathrm{~g}$ for mussel consumers. The maximum portion size reported in this study was $1500 \mathrm{~g}$. The French CALIPSO study differentiated between mussels and bivalve molluscs. The maximum portions for mussels and bivalve molluscs were $245 \mathrm{~g}$ and $415 \mathrm{~g}$, respectively. The mean portion sizes were $22 \mathrm{~g}$ and $32 \mathrm{~g}$, and the $95^{\text {th }}$ percentile $70 \mathrm{~g}$ and $94 \mathrm{~g}$ for mussels and bivalve molluscs, respectively. A survey reported by the UK indicated a mean shellfish portion size of $114 \mathrm{~g}$ and a maximum of $239 \mathrm{~g}$. The Italian study reported a mean portion size of $83 \mathrm{~g}$ and a maximum of $1000 \mathrm{~g}$. A Dutch study reported a mean portion size of $136 \mathrm{~g}$ of shellfish, a $95^{\text {th }}$ percentile of $465 \mathrm{~g}$ and a maximum of $480 \mathrm{~g}$. All these data reflect the target population, because they concern consumers only. It should be noted that the surveys show a large variation in the percentage of the populations consuming shellfish and it is unclear whether the data are related to cooked or uncooked shellfish.

Because marine biotoxins have acute toxic effects, it is important to use a large portion size rather than long term average consumption in dietary exposure calculations, to ensure protection of the health of consumers of shellfish against acute effects. In the studies presented in Table 1, the maximum reported sizes are in the range of 239 to $1500 \mathrm{~g}$. The CONTAM Panel noted the reported largest portion sizes of $1000 \mathrm{~g}$ and $1500 \mathrm{~g}$, and considered it likely that the shells were included in these weight estimates. Therefore, the CONTAM Panel considered the $95^{\text {th }}$ percentile as a more realistic estimate of the portion size for high consumers. As shown in Table 1 the $95^{\text {th }}$ percentile values range from $70 \mathrm{~g}$ to $465 \mathrm{~g}$. The CONTAM Panel chose the figure of $400 \mathrm{~g}$, which is at the higher end of the range but below the highest reported value, as a reasonable large portion size to be used in the risk assessment, in order to protect high consumers against acute effects of marine biotoxins. This figure was in good agreement with the report of the Joint FAO/IOC/WHO ad hoc expert consultation on marine biotoxins (FAO/IOC/WHO, 2004), where $380 \mathrm{~g}$ was reported as the $97.5^{\text {th }}$ percentile largest portion size for consumers only. 
Table 1: Shellfish eating habits in France, Italy, the Netherlands, the UK and Germany, based on national food consumption surveys submitted to EFSA in 2007.

\begin{tabular}{|c|c|c|c|c|c|c|c|}
\hline Country & Study & $\begin{array}{l}\text { Number of } \\
\text { consumers } \\
\text { n ( } \%)\end{array}$ & $\begin{array}{l}\text { Number of } \\
\text { eating occasions } \\
\text { for } \\
\text { consumers/year }\end{array}$ & $\begin{array}{l}\text { Mean } \\
\text { portion } \\
\text { weight } \\
\text { (g) }\end{array}$ & $\begin{array}{l}\text { P95 } \\
\text { (g) }\end{array}$ & $\begin{array}{l}\text { Maximum } \\
\text { portion } \\
\text { weight } \\
\text { (g) }\end{array}$ & $\begin{array}{l}\text { Maximu } \\
\text { m } \\
\text { frequency }\end{array}$ \\
\hline $\begin{array}{l}\text { France } \\
(7 \text { days })\end{array}$ & $\begin{array}{l}\text { INCA } \\
1999\end{array}$ & $\begin{array}{l}218 / 1985 \\
(11 \%)\end{array}$ & N/A & 10 & & & N/A \\
\hline $\begin{array}{l}\text { France } \\
\text { (FFQ) }\end{array}$ & $\begin{array}{l}\text { CALIPSO } \\
2004 \\
\text { (bivalve } \\
\text { molluscs) }\end{array}$ & $\begin{array}{l}962 / 997 \\
(96 \%)\end{array}$ & N/A & 32 & 94 & 415 & N/A \\
\hline $\begin{array}{l}\text { France } \\
\text { (FFQ) }\end{array}$ & $\begin{array}{l}\text { CALIPSO } \\
2004 \\
\text { (mussels) }\end{array}$ & $\begin{array}{l}862 / 997 \\
(86 \%)\end{array}$ & N/A & 22 & 70 & 245 & N/A \\
\hline $\begin{array}{l}\text { Italy } \\
\text { (7 days) }\end{array}$ & $\begin{array}{l}\text { INN-CA } \\
1994-96\end{array}$ & $\begin{array}{l}212 / 1981 \\
(11 \%)\end{array}$ & 47 & 83 & & 1000 & 4/week \\
\hline $\begin{array}{l}\text { Germany } \\
\text { (7 days) }\end{array}$ & $\begin{array}{l}\text { NVS } \\
1985-88\end{array}$ & $\begin{array}{l}150 / 23239 \\
(0.6 \%)\end{array}$ & 171 & 107 & 400 & 1500 & 3/week \\
\hline $\begin{array}{l}\text { UK } \\
\text { (7 days) }\end{array}$ & $\begin{array}{l}\text { NDNS } \\
2000-01\end{array}$ & $\begin{array}{l}212 / 1631 \\
(13 \%)\end{array}$ & 51 & 114 & & 239 & 4/week \\
\hline $\begin{array}{l}\text { The Netherlands } \\
\text { (2 days) }\end{array}$ & $\begin{array}{l}\text { DNFCS } \\
1997-98\end{array}$ & $\begin{array}{l}47 / 4285 \\
(1.1 \%)\end{array}$ & 39 & 136 & 465 & 480 & N/A \\
\hline \multicolumn{8}{|c|}{$\begin{array}{l}\text { FFQ: food frequency questionnaire; } 7 \text { days: } 7 \text { day dietary record; } 2 \text { days: } 2 \text { day dietary record; N/A: not available; } \\
\text { n: number of consumers; P95: } 95^{\text {th }} \text { percentile. } \\
\text { INCA: Enquête Individuelle et Nationale sur les Consommations Alimentaires (Volatier, 2000). } \\
\text { CALIPSO: Fish and seafood consumption study and biomarker of exposure to trace elements, pollutants and omega } 3 \\
\text { (Leblanc et al., 2006). } \\
\text { INN-CA: Nationwide Nutritional Survey of Food Behaviour (Turrini et al., 2001). } \\
\text { NVS: Nationale Verzehrsstudie (Adolf et al., 1995). } \\
\text { NDNS: National Diet and Nutrition Survey (Henderson et al., 2002). } \\
\text { DNFCS: Dutch National Food Consumption Survey (Kistemaker et al., 1998). }\end{array}$} \\
\hline
\end{tabular}

\subsection{Consumption data submitted by Belgium, France, Portugal and Spain to EC/EFSA in 2009}

Recently Belgium, France, Portugal and Spain (Galicia) submitted new data on the consumption of shellfish to the EC which were forwarded to EFSA. The quality of these data was evaluated in order to decide if they were suitable to assess whether the CONTAM Panel's established estimate on the consumption figure of $400 \mathrm{~g}$ shellfish meat is appropriate. It was noted that the Belgian data are included in the EFSA Comprehensive Database (Table 2). The data provided by Spain were not considered suitable because they were based on average weekly consumption and not on daily consumption, and were for the general Spanish population and not for consumers only. The data from Portugal were also not suitable because they were based on the total production volume of shellfish divided by the size of the population of Portugal. The data provided by France were from the CALIPSO study (Leblanc et al., 2006) and the INCA2 study (AFSSA, 2009a). The consumption data reported in the CALIPSO study (Leblanc et al., 2006) concerned consumers only and were collected by food frequency questionnaires (FFQ) in selected areas in France between October 2004 and December 2004. They had already been included in the previous scientific opinions on marine biotoxins. However, in the latest data submission to EC/EFSA the consumption data from the CALIPSO study (Leblanc et al., 2006) were recalculated by AFSSA (AFSSA, 2009b). The recalculated consumption portion sizes provided by AFSSA show that the $95^{\text {th }}$ percentile for the portion size of bivalve molluscs is $300 \mathrm{~g}$ (the maximum being $1000 \mathrm{~g}$ ). This $95^{\text {th }}$ percentile is 
approximately 3 times higher than the one included in Table 1 . For mussels the $95^{\text {th }}$ percentile was $80 \mathrm{~g}$ (AFSSA, 2009b). The maximum frequency for consuming these portions varied from 3 to 4 times per week for mussels and from 1 to 7 times per week for bivalve molluscs (AFSSA, 2009b). Consequently, the previously reported $95^{\text {th }}$ percentiles as included in Table 1 now change into: $80 \mathrm{~g}$ (France, mussels), $300 \mathrm{~g}$ (France, bivalve molluscs), $400 \mathrm{~g}$ (Germany), and $465 \mathrm{~g}$ (The Netherlands). The consumption data of the INCA2 study (AFSSA, 2009a) are included in the EFSA Comprehensive Database (Table 2).

\subsection{Consumption data in EFSA Comprehensive Database}

Twenty MSs have submitted food consumption data to the EFSA Comprehensive Database based on consumption surveys in the general population. These data are considered the most representative for the consumption of shellfish by the general population in Europe. The EFSA Comprehensive Database includes individual consumption figures at the eating occasion level. The database also includes information on consumption of shellfish and/or individual types of shellfish. Hence these consumption data, which include the before mentioned French (INCA 2 study) and Belgian consumption data, were used to assess whether the CONTAM Panel's established estimate of the consumption figure of $400 \mathrm{~g}$ shellfish meat is an appropriate figure for the assessment of acute risks following consumption of shellfish.

Information on the time period for collecting the data now included in the EFSA Comprehensive database is presented in Table 2. The consumption data from most of the MSs were collected after 2000. Only the data from Estonia, Ireland, Spain and Sweden were collected earlier than this. 
Table 2: Dietary surveys included in the EFSA Comprehensive Database.

\begin{tabular}{|c|c|c|}
\hline Member state & Name of the dietary survey & Reference for publication \\
\hline Austria & Austrian Study on Nutritional Status, ASNS & Elmadfa et al. (2008) \\
\hline Belgium & Diet National 2004 & De Vriese et al. (2005) \\
\hline Bulgaria & National Survey of Food Intake and Nutritional Status & Petrova and Angelova (2006) \\
\hline Bulgaria II & NUTRICHILD & Petrova et al. (2009) \\
\hline Czech Republic & $\begin{array}{l}\text { Individual Food Consumption - the National Survey, } \\
\text { SISP04 }\end{array}$ & Ruprich et al. (2006) \\
\hline Denmark & $\begin{array}{l}\text { Danish National Survey of Dietary Habits and Physical } \\
\text { Activity }\end{array}$ & Lyhne et al. (2005) \\
\hline Estonia & National Diet Survey 1997 & Pomerleau et al. (1999) \\
\hline Finland & National Findiet Study, FINDIET 2007 & Paturi et al. (2008) \\
\hline France & $\begin{array}{l}\text { Enquête Individuelle et Nationale } \\
\text { Consommations Alimentaires, INCA2 }\end{array}$ & $\begin{array}{l}\text { AFSSA (2009a); Lioret et al. } \\
\text { (2010); Dubuisson et al. (2010) }\end{array}$ \\
\hline Germany & German National Nutrition Survey II, NVS II & $\begin{array}{l}\text { MRI (2008); Krems et al. } \\
(2006)\end{array}$ \\
\hline Hungary & National Representative Survey & Rodler et al. (2005) \\
\hline Ireland & $\begin{array}{l}\text { North/South Ireland Food Consumption Survey, } \\
\text { NSIFCS }\end{array}$ & $\begin{array}{l}\text { Kiely et al. (2001); } \\
\text { Harrington et al. (2001) }\end{array}$ \\
\hline Italy & $\begin{array}{l}\text { Italian National Food Consumption Survey, INRAN- } \\
\text { SCAI 2005-06 }\end{array}$ & Leclercq et al. (2009) \\
\hline Latvia & EFSA_TEST & Šantare et al. (2008) \\
\hline The Netherlands & $\begin{array}{l}\text { Voedselconsumptiepeiling onder jongvolwassenen, VCP } \\
2003\end{array}$ & Ocké et al. (2005) \\
\hline Poland & $\begin{array}{l}\text { Food and Nutrition Institute-Food and Agriculture } \\
\text { Organization of the United Nations, IZZ-FAO } 2000\end{array}$ & $\begin{array}{l}\text { Sekula et al. (2004) } \\
\text { Szponar et al. }(2001,2003)\end{array}$ \\
\hline Slovakia & Slovakia MON 2008 & Not available \\
\hline Slovenia & Targeted research project, CRP 2008 & $\begin{array}{l}\text { Gabrijelčič Blenkuš et al. } \\
\text { (2009) }\end{array}$ \\
\hline Spain I & $\begin{array}{l}\text { Spanish Food Safety and Nutrition Authority- Spanish } \\
\text { Food and Drink Industry Federation, AESAN-Fiab }\end{array}$ & Requejo et al. (2002) \\
\hline Spain II & Spanish Food Safety and Nutrition Authority, AESAN & Ortega et al. (2010) \\
\hline Sweden & National Food Survey, RIKSMATEN 1997-98 & Becker and Pearson (2002) \\
\hline United Kingdom & National Diet and Nutrition Survey, NDNS & Henderson et al. (2002) \\
\hline
\end{tabular}

The design characteristics of the consumption surveys carried out by the different MSs are presented in Table 3. Four different types of survey methodology can be identified: 7 day food records (carried out in 5 surveys), 3 day food records (3 surveys), one-day 24 hour recalls (6 surveys) and two-day 24 hour dietary recalls ( 7 surveys). Only Finland, with a 48 hour dietary recall method, does not fit into any of these types of surveys. 
Table 3: Methods used in the dietary surveys.

\begin{tabular}{|c|c|c|c|c|}
\hline Country & Method & $\begin{array}{l}\text { Number of } \\
\text { replicates }\end{array}$ & Survey period & $\begin{array}{l}\text { Age range } \\
\text { (years) }\end{array}$ \\
\hline Austria & 24 hour dietary recall & 1 & May 2005 - February 2006 & $19-64$ \\
\hline Belgium & 24 hour dietary recall & 2 & February 2004 - February 2005 & $14-105$ \\
\hline Bulgaria & 24 hour dietary recall & 1 & March 2004 - August 2004 & $16-95$ \\
\hline Bulgaria II & 24 hour dietary recall & 2 & April 2007 - August 2007 & $0.1-5$ \\
\hline Czech Republic & 24 hour dietary recall & 2 & November 2003 - November 2004 & $16-64$ \\
\hline Denmark & Food record & 7 & June 2000 - December 2002 & $4-75$ \\
\hline Estonia & 24 hour dietary recall & 1 & March 1997 - September 1997 & $19-65$ \\
\hline Finland & 48 hour dietary recall & 1 & January 2007 - March 2007 & $25-74$ \\
\hline France & Food record & 7 & December 2005 - April 2007 & $3-79$ \\
\hline Germany & 24 hour dietary recall & 2 & November 2005 - January 2007 & $14-80$ \\
\hline Hungary & Food record & 3 & October 2003 - December 2003 & $18-96$ \\
\hline Ireland & Food record & 7 & October 1997 - October 1999 & $20-65$ \\
\hline Italy & Food record & 3 & October 2005 - December 2006 & $0.1-98$ \\
\hline Latvia & 24 hour dietary recall & 2 & June 2008 - November 2008 & $7-66$ \\
\hline The Netherlands & 24 hour dietary recall & 2 & October 2003 - December 2003 & $19-30$ \\
\hline Poland & 24 hour dietary recall & 1 & September 2000 - November 2000 & $1-96$ \\
\hline Slovakia & 24 hour dietary recall & 1 & January 2008 - December 2008 & $17-68$ \\
\hline Slovenia & 24 hour dietary recall & 1 & September 2007 - April 2008 & $18-65$ \\
\hline Spain I & Food record & 3 & January 1999 - November 2001 & $17-60$ \\
\hline Spain II & 24 hour dietary recall & 2 & January 2009 - September 2009 & $18-60$ \\
\hline Sweden & Food record & 7 & January 1997 - January 1998 & $17-79$ \\
\hline United Kingdom & Food record & 7 & July 2000 - June 2001 & $19-64$ \\
\hline
\end{tabular}

Data on consumption of shellfish were included in 14 out of the 22 studies included in the EFSA Comprehensive Database. Table 4 shows the percentage of consumers of different shellfish types for each of these countries. There is a large variation in the percentage of consumers amongst the different MSs. Only in France and Spain does the percentage of consumers of total shellfish exceed $10 \%$ of the population. For Italy the percentage of consumers is $9.4 \%$, and for all other countries the figure is less than $2.8 \%$. The column "Total shellfish" in Table 4 refers to consumers of at least one type of shellfish among clams, cockles, mussels, oysters and scallops. ${ }^{11}$ Comparing the figures for total shellfish with those for the single shellfish types reveals that in some cases the same consumer reported consumption of more than one type of shellfish. It is also important to note that consumers who consumed shellfish within recipes, even in small quantities, are included among the shellfish consumers. This is because MSs were asked, as much as possible, to disaggregate industrially produced composite foods or home-made dishes, such as a ready-made frozen pizza or a home cooked beef stew, into their main ingredients at a level that can be reported by the consumers e.g. in the case of a sandwich with ham and butter it was requested to distinguish between the three components such as bread, ham and butter.

\footnotetext{
${ }^{11}$ The term "shellfish" is used to group a broad variety of molluscs, crustaceans and echinoderms. However, the scope of the present statement is limited to bivalve molluscs and therefore in this statement "total shellfish" comprises only clams, cockles, mussels, oysters and scallops.
} 
The total consumption for each shellfish type and for total shellfish was calculated per individual and day taking into consideration only the consuming days. The number of consuming days per country and shellfish types (clams, cockles, mussels, oysters and scallops) together with a reliable estimate of the $95^{\text {th }}$ percentile consumption is presented in Table 5. For each country, an estimate of the $95^{\text {th }}$ percentile consumption of total shellfish is also reported, comprising the data reported also separately for the different shellfish types (Table 5). The number of shellfish consuming days among all days reported by all the subjects in the survey ranged from 1 day (in Bulgaria) to 635 days (in France) but the highest percentage of consuming days out of the total number of reporting/recall days was calculated for Spain (AESAN-Fiab dietary survey) where total shellfish was consumed at $18.8 \%$ of the record days (Table 5).

Based on the information present in the EFSA Comprehensive Database it was possible to estimate the number of days for which a certain consumption of total shellfish would be exceeded. The proportions of consuming days exceeding $100 \mathrm{~g}$ were $0.5 \%$ (Spain I), $3 \%$ (Spain II), $9 \%$ (Ireland), $13 \%$ (Italy), $14 \%$ (Finland), $18 \%$ (Germany), $19 \%$ (UK), $24 \%$ (France) and $48 \%$ (Belgium) while the proportions of consuming days exceeding $200 \mathrm{~g}$ were $2 \%$ (Italy), $2.5 \%$ (France), $4 \%$ (Ireland), $7 \%$ (UK), $11 \%$ (Belgium) and $15 \%$ (Germany).

A non-parametric method is used to calculate confidence intervals for the $95^{\text {th }}$ percentile (Conover, 1971). This method does not assume any given distribution for the data, e.g. (log-) normal distribution. For the calculations of the results presented in Table 5 this method was implemented in the SAS software. ${ }^{12}$ The significance level $(\alpha)$ is set at 0.05 to determine a $95 \%$ confidence interval. The coverage probability of each non-parametric $95 \%$ confidence interval is also calculated as described in the SAS manual. ${ }^{12}$ In statistics, the coverage probability of a confidence interval is the probability that the interval contains the true value of interest (here $95^{\text {th }}$ percentile) as presented in Table 5. For a statistical value, like the mean or a percentile of a set of data, the confidence interval aims to contain the "true" value with a given probability. This probability is a nominal value used by the procedure for constructing the confidence intervals and is often set at $95 \%$. The coverage probability is evaluated after calculating the confidence interval and represents the actual probability that the calculated interval contains the true value. When the number of observations is not large enough, the coverage probability does not attain the nominal value, e.g. $95 \%$. This is more likely to occur at high percentiles, e.g. $95^{\text {th }}$ or $99^{\text {th }}$. Therefore, in this assessment the coverage probability is used to evaluate the uncertainty of the calculated $95^{\text {th }}$ percentiles of the portion sizes. The CONTAM Panel decided that in this statement the coverage probability should be at least $95 \%$.

As presented in Table 5 the calculated $95^{\text {th }}$ percentile consumption figures presenting a coverage probability not lower than $95 \%$ were $63 \mathrm{~g}$ for mussels and $75 \mathrm{~g}$ for total shellfish for Spain, $162 \mathrm{~g}$ for total shellfish for Italy, $200 \mathrm{~g}$ for scallops in France and $251 \mathrm{~g}$ for total shellfish for Belgium. The CONTAM Panel noted that the upper confidence limit of the highest $95^{\text {th }}$ percentile of consumption $(251 \mathrm{~g})$ is $500 \mathrm{~g}$. Also the data from Germany for total shellfish indicated a high $95^{\text {th }}$ percentile of consumption of $338 \mathrm{~g}$, with an upper confidence limit of $525 \mathrm{~g}$ (Table 5). The CONTAM Panel noted however, that the coverage probability for this figure was lower than $95 \%$, and therefore these data were not further used in the assessment.

\footnotetext{
${ }^{12}$ For details of the methods used to calculate the $95^{\text {th }}$ percentile values, the $95 \%$ confidence intervals and their coverage probability see Base SAS(R) 9.2 Procedures Guide: Statistical Procedures, Third Edition. http://support.sas.com/documentation/cdl/en/procstat/63104/HTML/default/viewer.htm\#/documentation/cdl/en/procstat/6 3104/HTML/default/procstat_univariate sect028.htm.
} 
Marine Biotoxins in Shellfish -

Table 4: Number of consumers by shellfish type and by country.

\begin{tabular}{|c|c|c|c|c|c|c|c|c|c|c|c|c|c|}
\hline \multirow{3}{*}{ Country } & \multirow{3}{*}{$\begin{array}{c}\text { Number } \\
\text { of } \\
\text { subjects }\end{array}$} & \multicolumn{12}{|c|}{ Number and percentage consumers of } \\
\hline & & \multicolumn{2}{|c|}{ Clams } & \multicolumn{2}{|c|}{ Cockles } & \multicolumn{2}{|c|}{ Mussels } & \multicolumn{2}{|c|}{ Oysters } & \multicolumn{2}{|c|}{ Scallops } & \multicolumn{2}{|c|}{ Total shellfish $^{(a)}$} \\
\hline & & $\mathbf{n}$ & $\%$ & $\mathbf{n}$ & $\%$ & $\mathbf{n}$ & $\%$ & $\mathbf{n}$ & $\%$ & $\mathbf{n}$ & $\%$ & $\mathbf{n}$ & $\%$ \\
\hline Austria & 2123 & & 0.0 & & 0.0 & 2 & 0.1 & & 0.0 & & 0.0 & 2 & 0.1 \\
\hline Belgium & 3245 & & 0.0 & & 0.0 & 73 & 2.2 & 9 & 0.3 & 12 & 0.4 & 91 & 2.8 \\
\hline Bulgaria & 1204 & & 0.0 & & 0.0 & 3 & 0.2 & & 0.0 & & 0.0 & 3 & 0.2 \\
\hline Germany & 13926 & & 0.0 & & 0.0 & 27 & 0.2 & 4 & 0.0 & 9 & 0.1 & 40 & 0.3 \\
\hline Estonia & 1866 & & 0.0 & & 0.0 & & 0.0 & 1 & 0.1 & & 0.0 & 1 & 0.1 \\
\hline Spain I & 1068 & 197 & 18.4 & 15 & 1.4 & 315 & 29.5 & & 0.0 & 2 & 0.2 & 358 & 33.5 \\
\hline Spain II & 418 & 22 & 5.3 & 2 & 0.5 & 46 & 11.0 & & 0.0 & 1 & 0.2 & 55 & 13.2 \\
\hline Finland & 2038 & & 0.0 & & 0.0 & 12 & 0.6 & & 0.0 & & 0.0 & 12 & 0.6 \\
\hline France & 4079 & 5 & 0.1 & & 0.0 & 232 & 5.7 & 137 & 3.4 & 176 & 4.3 & 492 & 12.1 \\
\hline United Kingdom & 1724 & 1 & 0.1 & 4 & 0.2 & 27 & 1.6 & 2 & 0.1 & 16 & 0.9 & 45 & 2.6 \\
\hline Ireland & 958 & 1 & 0.1 & & 0.0 & 15 & 1.6 & & 0.0 & 7 & 0.7 & 17 & 1.8 \\
\hline Italy & 3323 & 189 & 5.7 & & 0.0 & 147 & 4.4 & 1 & 0.0 & 2 & 0.1 & 312 & 9.4 \\
\hline The Netherlands & 750 & & 0.0 & & 0.0 & 9 & 1.2 & & 0.0 & & 0.0 & 9 & 1.2 \\
\hline Sweden & 1210 & & 0.0 & & 0.0 & 4 & 0.3 & & 0.0 & & 0.0 & 4 & 0.3 \\
\hline
\end{tabular}

(a): Total shellfish comprises clams, cockles, mussels, oysters and scallops. ${ }^{1}$ 
Marine Biotoxins in Shellfish efsa.

Further elaboration of the consumption figure of $400 \mathrm{~g}$ shellfish meat on the basis of new consumption data

Table 5: $\quad 95^{\text {th }}$ percentile of consumption reported by shellfish type and by country.

\begin{tabular}{|c|c|c|c|c|c|c|c|}
\hline \multirow[b]{2}{*}{ Country } & \multirow[b]{2}{*}{ Shellfish types } & \multicolumn{2}{|c|}{ Consuming days } & \multicolumn{4}{|c|}{$95^{\text {th }}$ percentile of consumption among consuming days only } \\
\hline & & Number & $\%$ & $\begin{array}{l}\text { Estimate } \\
\text { (g/day) }\end{array}$ & $\begin{array}{c}\text { Lower confidence } \\
\text { limit } \\
\text { (g/day) }\end{array}$ & $\begin{array}{c}\text { Upper confidence } \\
\text { limit } \\
\text { (g/day) }\end{array}$ & $\begin{array}{c}\text { Coverage probability } \\
\text { (\%) }\end{array}$ \\
\hline \multirow{2}{*}{ Austria } & Mussels & $2^{(\mathrm{a})}$ & 0.1 & 38 & & & \\
\hline & Total shellfish $^{(b)}$ & $2^{(\mathrm{a})}$ & 0.1 & 38 & & & \\
\hline \multirow{4}{*}{ Belgium } & Mussels & 73 & 1.2 & 250 & 180 & 500 & 97 \\
\hline & Oysters & $9^{(a)}$ & 0.1 & 252 & & & \\
\hline & Scallops & 12 & 0.2 & 160 & 70 & 160 & 44 \\
\hline & Total shellfish $^{(b)}$ & 94 & 1.5 & 251 & 201 & 500 & 97 \\
\hline \multirow{2}{*}{ Bulgaria } & Mussels & 3 & 0.2 & 200 & & & \\
\hline & Total shellfish $^{(b)}$ & 3 & 0.2 & 200 & & & \\
\hline \multirow{4}{*}{ Germany } & Mussels & 27 & 0.1 & 375 & 300 & 525 & 60 \\
\hline & Oysters & $4^{(a)}$ & 0.0 & 60 & & & \\
\hline & Scallops & $9^{(a)}$ & 0.0 & 98 & & & \\
\hline & Total shellfish $^{(b)}$ & 40 & 0.1 & 338 & 250 & 525 & 82 \\
\hline \multirow{2}{*}{ Estonia } & Oysters & $1^{\text {(a) }}$ & 0.1 & 30 & & & \\
\hline & Total shellfish $^{(b)}$ & $1^{\text {(a) }}$ & 0.1 & 30 & & & \\
\hline \multirow{5}{*}{ Spain I } & Clams & 209 & 7.0 & 50 & 23 & 63 & 96 \\
\hline & Cockles & 15 & 0.5 & 20 & 15 & 20 & 50 \\
\hline & Mussels & 333 & 11.2 & 63 & 44 & 70 & 95 \\
\hline & Scallops & $2^{(\mathrm{a})}$ & 0.1 & 63 & & & \\
\hline & Total shellfish $^{(b)}$ & 559 & 18.8 & 53 & 44 & 63 & 96 \\
\hline \multirow{5}{*}{ Spain II } & Clams & 22 & 2.7 & 20 & 16 & 50 & 58 \\
\hline & Cockles & $2^{(\mathrm{a})}$ & 0.2 & 2 & & & \\
\hline & Mussels & 49 & 5.9 & 85 & 70 & 100 & 82 \\
\hline & Scallops & $1^{(\mathrm{a})}$ & 0.1 & 40 & & & \\
\hline & Total shellfish $^{(b)}$ & 74 & 8.9 & 75 & 50 & 100 & 97 \\
\hline \multirow{2}{*}{ Finland } & Mussels & 14 & 0.3 & 160 & 44 & 160 & 48 \\
\hline & Total shellfish $^{(b)}$ & 14 & 0.3 & 160 & 44 & 160 & 48 \\
\hline
\end{tabular}


Marine Biotoxins in Shellfish efsa.

Further elaboration of the consumption figure of $400 \mathrm{~g}$ shellfish meat on the basis of new consumption data

Table 5: Continued

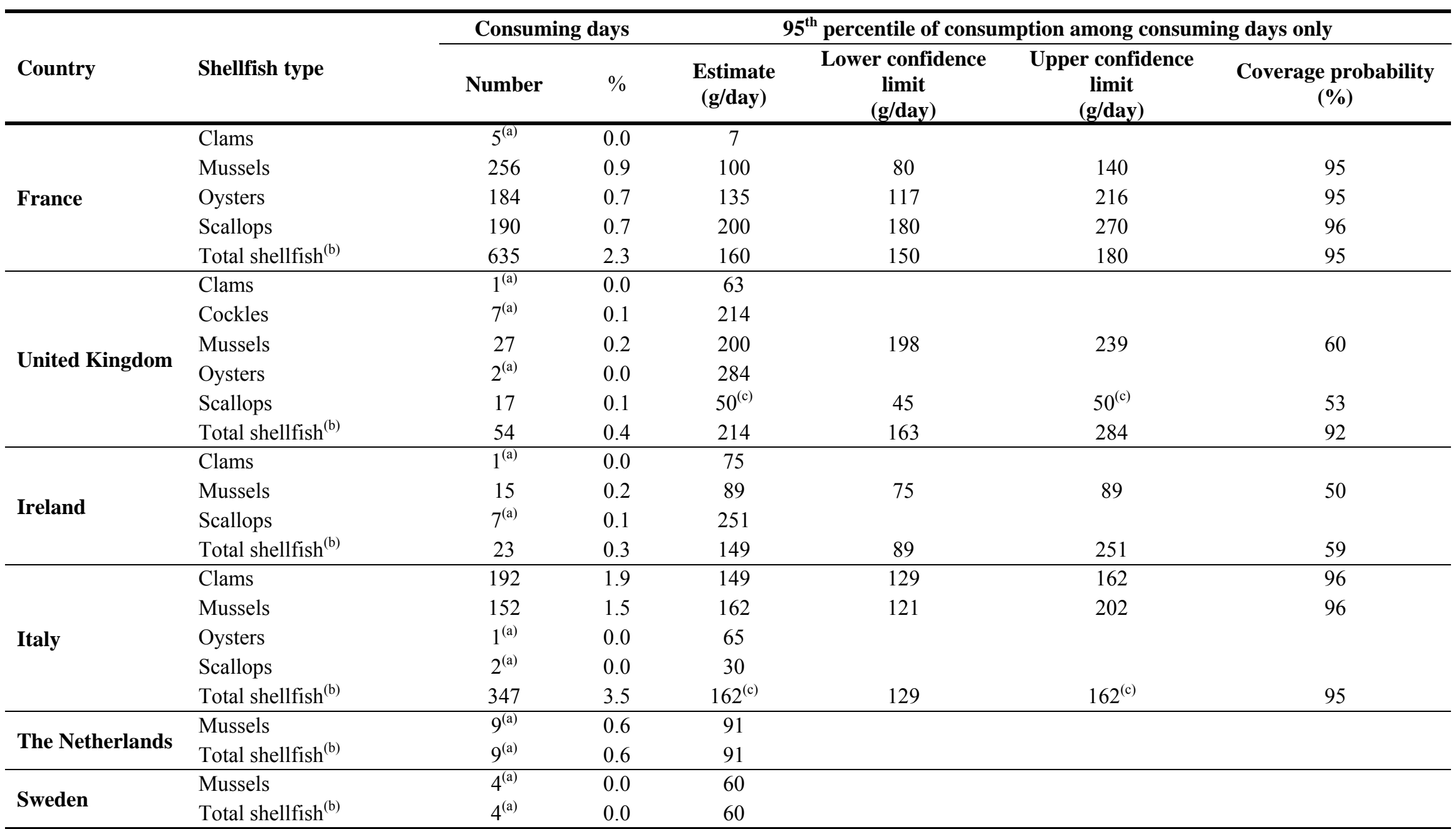

(a): The confidence interval and the coverage probability were not calculated when the number of consuming days was below 10; (b): Total shellfish comprises clams, cockles, mussels, oysters and scallops ${ }^{11}$ (c): It is possible that different days present the same quantity of consumption, because when the consumed amounts were reported by the subjects the standard portion sizes were used. This is the reason why the estimate for the $95^{\text {th }}$ percentile of consumption can be equal to its upper confidence limit. 


\section{Appropriateness of the consumption figure of $400 \mathrm{~g}$}

The new shellfish consumption data submitted by Spain and Portugal were not suitable to assess the CONTAM Panel's earlier established estimate of the consumption figure of $400 \mathrm{~g}$ shellfish meat. The recalculated consumption data submitted to EC/EFSA by France indicate a $95^{\text {th }}$ percentile of consumption of mussels of $80 \mathrm{~g}$ and of bivalve molluscs of $300 \mathrm{~g}$. Consequently, the previously reported $95^{\text {th }}$ percentiles as included in Table 1 now change into: $80 \mathrm{~g}$ (France, mussels), $300 \mathrm{~g}$ (France, bivalve molluscs), $400 \mathrm{~g}$ (Germany), and $465 \mathrm{~g}$ (The Netherlands). These figures support the CONTAM Panel's earlier established estimate of a large portion size of $400 \mathrm{~g}$ of shellfish meat.

The data on the consumption of shellfish that are included in the EFSA Comprehensive Database show $95^{\text {th }}$ percentile for portions sizes ranging from 63-251 g. The upper confidence limit of the highest $95^{\text {th }}$ percentile with at least $95 \%$ coverage probability ( $251 \mathrm{~g}$ for total shellfish in Belgium) is $500 \mathrm{~g} /$ day. The value of $500 \mathrm{~g}$ can be considered as a rather conservative estimate of high consumer shellfish consumption in Europe. Hence the consumption data included in the EFSA Comprehensive Database also do not warrant a revision of the CONTAM Panel's earlier established estimate on the consumption figure of $400 \mathrm{~g}$ shellfish meat.

Overall the CONTAM Panel concluded that the earlier estimate of a large portion size of $400 \mathrm{~g}$ shellfish meat is appropriate for protecting high consumers against acute effects of marine biotoxins.

\section{Uncertainty}

The earlier identification of $400 \mathrm{~g}$ of shellfish meat as a large portion size to be used in the acute risk assessment of marine biotoxins by the CONTAM Panel was based on consumption data provided by five member states. This limited information of shellfish consumption in Europe as well as the limited representative data on shellfish types other than mussels introduced considerable uncertainty. Additional consumption data recently provided by Spain and Portugal were not suitable for assessment of the large portion size. Additional data (CALIPSO study) provided by France narrowed the uncertainty of the $95^{\text {th }}$ percentile and therefore decreased the uncertainty in the earlier estimated consumption figure of $400 \mathrm{~g}$.

Additional data provided by Belgium and France (INCA2) were included in the EFSA Comprehensive Database. The evaluation of the data on shellfish consumption submitted by 14 member states to the EFSA Comprehensive Database indicates that these are also mainly based on limited consumption data as well as different methodologies. The confidence intervals show wide ranges of the $95^{\text {th }}$ percentiles which are indicative of appreciable uncertainty. If the highest upper confidence limits of the $95^{\text {th }}$ percentile of the portion size with at least $95 \%$ coverage probability for each member state are taken as a conservative estimate, then the $400 \mathrm{~g}$ portion size is either an overestimation or underestimation depending on the member state. Only in Belgium and Germany does the upper $95 \%$ confidence interval exceed $400 \mathrm{~g}$, and by only approximately $20 \%$.

\section{CONCLUSIONS}

- Because marine biotoxins have acute toxic effects, the Panel on Contaminants in the food chain (CONTAM Panel) considered it is important to use a large portion size rather than a long term average consumption in dietary exposure calculations, to ensure protection of the health also of high consumers.

- The CONTAM Panel estimated that the proportions of consuming days exceeding $100 \mathrm{~g}$ shellfish were 0.5-3 \% (Spain), $9 \%$ (Ireland), $13 \%$ (Italy), $14 \%$ (Finland), $18 \%$ (Germany), $19 \%$ (UK), $24 \%$ (France) and $48 \%$ (Belgium), and the proportions of consuming days 
exceeding 200 g shellfish were $2 \%$ (Italy), $2.5 \%$ (France), $4 \%$ (Ireland), $7 \%$ (UK), $11 \%$ (Belgium) and $15 \%$ (Germany).

- The CONTAM Panel considered the $95^{\text {th }}$ percentile as a realistic estimate of the large portion size for high consumers.

- Based on the assessment of the new data provided to EFSA and the information included in the EFSA Comprehensive Database, the CONTAM Panel concluded that the earlier established estimate of the consumption figure of $400 \mathrm{~g}$ shellfish meat is appropriate for protecting high consumers against acute effects of marine biotoxins.

\section{DOCUMENTATION PROVIDED TO EFSA}

AFSSA (Agence française de sécurité sanitaire des aliments), 2009b. Portion sizes and daily amounts of bivalve molluscs consumed in the CALIPSO study. $2^{\text {nd }}$ October 2009.

\section{REFERENCES}

Adolf T, Schneider R, Eberhardt W, Hartmann S, Herwig A, Heseker H, Hünchen K, Kübler W, Matiaske B, Moch KJ and Rosenbauer J, 1995. Band III Ergebnisse der Nationalen Verzehrsstudie (1985-1988) über die Lebensmittel- und Nährstoffaufnahme in der Bundesrepublik Deutschland, VERA Schriftenreihe. S 145 Abb 6.56.

AFSSA (Agence française de sécurité sanitaire des aliments), 2009a. Report of the 2006/2007 Individual and National Study on Food Consumption 2 (INCA 2). Synthèse de l'étude individuelle nationale des consommations alimentaires 2 (INCA 2) 2006-2007, 1-44.

AFSSA (Agence française de sécurité sanitaire des aliments), 2009b. Portion sizes and daily amounts of bivalve molluscs consumed in the CALIPSO study. 2nd October 2009.

Becker W and Pearson M, 2002. Riksmaten 1997-98, Kostvanor och näringsintag I Sverige. Metodoch resultatanalysis.(Dietary habits and nutrient intake in Sweden 1997-98) Livsmedelsverket (National Food Administration), 1-201. Available from http://www.slv.se/upload/dokument/rapporter/kostundersokningar/riksmat.pdf

Conover WJ, 1971. Practical Nonparametric Statistics. Wiley, New York, 462 pp.

De Vriese S, Huybrecht I, Moreau M, De Henauw S, De Backer G, Kornlitzer M, Leveque A and Van Oyen H, 2005. The Belgian food consumption survey: aim, design and methods. Archives of Public Health, 63, 1-16.

Dubuisson C, Lioret S, Touvier M, Dufour A, Calamassi-Tran G, Volatier JL and Lafay L, 2010. Trends in food and nutritional intakes of French adults from 1999 to 2007: results from the INCA surveys. British Journal of Nutrition, 103, 1035-1048.

EFSA (European Food Safety Authority), 2008a. Marine biotoxins in shellfish - okadaic acid and analogues - Scientific Opinion of the Panel on Contaminants in the Food Chain. The EFSA Journal, $589,1-62$.

EFSA (European Food Safety Authority), 2008b. Marine biotoxins in shellfish - Azaspiracid group Scientific Opinion of the Panel on Contaminants in the Food Chain. The EFSA Journal, 723, 1-52.

EFSA (European Food Safety Authority), 2008c. Marine biotoxins in shellfish - Yessotoxin group Scientific Opinion of the Panel on Contaminants in the Food Chain. The EFSA Journal, 907, 1-62.

EFSA (European Food Safety Authority), 2009a. Marine biotoxins in shellfish - Saxitoxin group. The EFSA Journal, 1019, 1-76. 
EFSA (European Food Safety Authority), 2009b. Marine biotoxins in shellfish - Pectenotoxin group Scientific Opinion of the Panel on Contaminants in the Food Chain. The EFSA Journal, 1109, $1-47$.

EFSA (European Food Safety Authority), 2009c. Marine biotoxins in shellfish - Domoic acid. The EFSA Journal, 1181, 1-61.

EFSA (European Food Safety Authority), 2009e. Influence of processing on the levels of lipophilic marine biotoxins in bivalve molluscs. The EFSA Journal, 1016, 1-10.

EFSA (European Food Safety Authority), 2009f. Marine biotoxins in shellfish - Summary on regulated marine biotoxins. The EFSA Journal, 1306, 1-23.

EFSA Panel on Contaminants in the Food Chain (CONTAM), 2009d. Scientific Opinion on marine biotoxins in shellfish - Palytoxin group. EFSA Journal, 7(12):1393, 38 pp.

EFSA Panel on Contaminants in the Food Chain (CONTAM), 2010a. Scientific Opinion on marine biotoxins in shellfish - Emerging toxins: Ciguatoxin group. EFSA Journal, 8(6):1627, 38 pp.

EFSA Panel on Contaminants in the Food Chain (CONTAM), 2010b. Scientific Opinion on marine biotoxins in shellfish - Cyclic imines (spirolides, gymnodimines, pinnatoxins and pteriatoxins). EFSA Journal, 8(6):1628, $39 \mathrm{pp}$.

EFSA Panel on Contaminants in the Food Chain (CONTAM), 2010c. Scientific Opinion on marine biotoxins in shellfish - Emerging toxins: Brevetoxin group. EFSA Journal, 8(7):1677, 36 pp.

Elmadfa I, Freisling H, Nowak V and Hofstädter D, 2009. Austrian Nutrition Report 2008 (Österreichischer Ernährungsbericht 2008). $1^{\text {st }}$ edition, Vienna.

FAO/IOC/WHO (Food and Agriculture Organization of the United Nations/Intergovernmental Oceanographic Commission of UNESCO/World Health Organization), 2004. In Background document of the Joint $\mathrm{FAO} / \mathrm{IOC} / \mathrm{WHO}$ ad hoc Expert Consultation on Biotoxins in Bivalve Molluscs, Oslo, Norway, September 26-30, 2004.

Gabrijelčič Blenkuš M, Gregorič M, Tivadar B, Koch V, Kostanjevec S, Turk Fajdiga V, Žalar A, Lavtar D, Kuhar D and Rozman U, 2009. Prehrambene navade odraslih prebivalcev Slovenije z vidika varovanja zdravja. Ljubljana, Pedagoška fakulteta, Inštitut za varovanje zdravja RS.

Harrington KE, Robson PJ, Kiely M, Livingstone MB, Lambe J and Gibney MJ, 2001. The North/South Ireland Food Consumption Survey: survey design and methodology. Public Health Nutrition, 4, 1037-1042.

Henderson L, Gregory J and Swan G, 2002. NDNS (National Diet and Nutrition Survey), National Diet and Nutrition Survey: Adults Aged 19 to 64 Years: volume 1: types and quantities of foods consumed, London: TSO.

Kiely M, Flynn A, Harrington KE, Robson PJ and Cran G, 2001. Sampling description and procedures used to conduct the North/South Ireland Food Consumption Survey. Public Health Nutrition, 4, 1029-1035.

Kistemaker C, Bouman M and Hulshof KFM, 1998. DNFCS (Dutch National Food Consumption Survey), Consumption of separate products by Dutch population groups - Dutch National Food Consumption Survey 1997-1998 (in Dutch), TNO-Nutrition and Food Research Institute, TNOreport V98.812, Zeist, The Netherlands.

Krems C, Bauch A, Gotez A, Heuer T, Hild A, Möseneder J and Borombach C, 2006. Methoden der nationalesn Verzehrstudie II. Ernahrungs umschau 53. Heft, 2, 44-50.

Leblanc J-C, Volatier J-L, Sirot V and Bemrah-Aouachria N, 2006. CALIPSO, Fish and seafood consumption study and biomarker of exposure to trace elements, pllutants and omega 3. The General Directorate for Foods of France's Ministry of Agriculture and Fisheries, AFSSA, the French Institute for Agronomy Research and the French Food Safety Agency INRA. 
Leclercq C, Arcella D, Piccinelli R, Sette S, Le Donne C and Turrini A, 2009. The Italian National Food Consumption Survey INRAN-SCAI 2005-06: main results in terms of food consumption. Public Health Nutrition, 12, 2504-2532.

Lioret S, Dubuisson C, Dufour A, Touvier M, Calamassi-Tran G, Maire B, Volatier JL and Lafay L, 2010. Trends in food intake in French children from 1999 to 2007: results from the INCA (Etude Individuelle Nationale des Consommations Alimentaires) dietary surveys. British Journal of Nutrition, 103, 585-601.

Lyhne N, Christensen T, Velsing G, Fagt S, Biltoft-Jensen A, Hartkopp H, Hinsch HJ, Matthiesen J, Moller A, Saxholt E and Trolle E, 2005. Danskernes kostvaner 2000-2002. Hovedresultater. Danmarks Fodevareforskning, 1-168.

MRI (Max Rubner-Institut), 2008. Ergebnisbericht der Nationalen Verzehrsstudie II - Teil 1 (in German: Report of the National Nutrition Survey II - Part 1). Karlsruhe (Germany), p. 144. Available from http://www.was-esse-ich.de/uploads/media/NVS_II_Abschlussbericht_Teil_1.pdf

Ocké MC, Hulshof KFAM and van Rossum CTM, 2005. The Dutch national food consumption survey 2003. Methodological issues. Archives of Public Health, 63, 227-241.

Ortega RM, López-Sobaler AM, Ballesteros JM, Pérez N, Rodríguez- Rodríguez E, Aparicio A, Perea JM and Andrés P, in press. Estimation of salt intake by 24-hour urinary sodium excretion in a representative sample of Spanish adults.

Paturi M, Tapanainen H and Reinivuo H, 2008. The National FINDIET 2007 Survey. (In Finnish, summary, figures and tables in English) No. B23. Helsinki: National Public Health Institute. Available from http://www.ktl.fi/attachments/suomi/julkaisut/julkaisusarja_b/2008/2008b23.pdf.

Petrova S and Angelova K, 2006. Food-Based Dietary Guidelines for Bulgarian adults - scientific background for development and formulation. Advances in Bulgarian Science, 4, 19-33.

Petrova S, Ovcharova D, Rangelova L, Duleva V, Angelova K, Kalinov K, Dimitrov P, Bojilova D, Baikova D, Vatralova K, Popivanova A, Marinova M, Antonova Z and Duneva Z, 2009. National survey on nutrition of infants and children under 5 years and family child rearing. A Report for UNICEF Bulgaria. NCPHP, 1-361 (In Bulgarian). Available from www.ncphp.government.bg.

Pomerleau J, McKee M, Robertson A, Vaask S, Pudule I, Grinberga D, Kadziauskiene K, Abaravicius A and Bartkeviciute R, 1999. Nutrition and lifestyle in the Baltic Republics. European centre on health of societies in transition and world health organization regional office for Europe, 1-61.

Requejo AM, Ortega AM, Lopez Sobaler AM, Navia B, Andres P, Jodral M, Quintas E, Redondo R, Menendez L, Perea JM, Aparicio A, Lozano MC, Bermejo L, Mena C, Faci M, Lolo JM, Rodriguez N, Cocho M, Diez C and Alvarez C, 2002. Estudio sobre dietas y habitos alimentarios en la poblacion Espanola. Consejo de seguridad nuclear, 1-303.

Rodler I, Biró L, Greiner E, Zajkás G, Szórád I, Varga A, Domonkos A, Agoston H, Balazs A, Mozsary E, Vitrai J, Hermann D, Boros J, Nemeth R and Zsuzsanna K, 2005. Taplalkozasi vizsgalat Magyarorszagon, 2003-2004. (Dietary survey in Hungary, 2003-2004) Orvosi Hetilap, 146. Evfolyam, 34, 1781-1789.

Ruprich J, Dofkova M, Rehurkova I, Slamenikova E and Resova D, 2006. Individual food consumption - the national study SISP04. CHFCH NIPH in Prague. Available from http://www.chpr.szu.cz/spotrebapotravin.htm.

Šantare D, Ozoliņš G and Joffe R, 2008. Latvijas iedzīvotāju pārtikas patēriṇa pētījums: mērḳi, norise, metodes. LLU Raksti, Jelgava, iesniegta publicēšanai.

Sekula W, Nelson M, Figurska K, Oltarzewski M, Weisell R and Szponar L, 2004. Comparison between household budget survey and 24 hour recall data in a nationally representative sample of Polish households. Public Health Nutrition, 8, 430-439. 
Szponar L, Sekuła W, Nelson M and Weisell RC, 2001. The Household Food Consumption and Anthropometric Survey in Poland. Public Health Nutrition, 4, 1183-1186.

Szponar L, Sekuła W, Rychlik E, Ołtarzewski M and Figurska K, 2003. Badania indywidualnego spożycia żywności i stanu odżywienia w gospodarstwach domowych (Household Food Consumption and Anthropometric Survey). NFNI Studies 101, Warszawa.

Turrini A, Saba A, Perrone D, Cialfa E and D'Amicis A, 2001. INN-CA (Nationwide Nutritional Survey of Food Behaviour). Food consumption patterns in Italy: the INN-CA Study 1994-1996. European Journal of Clinical Nutrition, 55, 571-588.

Volatier J-L 2000. INCA (Individuelle et Nationale sur les Consommations Alimentaires), Enquête INCA individuelle et nationale sur les consommations alimentaires. Agence Française de Sécurité Sanitaire des Aliments (AFSSA). Tech et Doc, Paris, 158 pp. 


\section{AbBreviations}

\begin{tabular}{|c|c|}
\hline AESAN & Spanish Food and Drink Industry Federation \\
\hline AESAN-Fiab & Spanish Food and Drink Industry Federation - Spanish dietary survey \\
\hline AFSSA & Agence française de sécurité sanitaire des aliments \\
\hline ASNS & Austrian Study on Nutritional Status \\
\hline AZA & Azaspiracid \\
\hline BTX & Brevetoxin \\
\hline CALIPSO & $\begin{array}{l}\text { Fish and seafood consumption study and biomarker of exposure to trace } \\
\text { elements, pollutants and omega } 3\end{array}$ \\
\hline $\mathrm{CI}$ & Cyclic imine \\
\hline CONTAM Panel & Panel on Contaminants in the Food Chain \\
\hline CRP & Slovenian dietary survey - Targeted research project \\
\hline CTX & Ciguatoxin \\
\hline DA & Domoic acid \\
\hline DNFCS & Dutch National Food Consumption Survey \\
\hline $\mathrm{EC}$ & European Commission \\
\hline EFSA & European Food Safety Authority \\
\hline EU & European Union \\
\hline FAO & Food and Agriculture Organization of the United Nations \\
\hline $\mathrm{FAO} / \mathrm{IOC} / \mathrm{WHO}$ & $\begin{array}{l}\text { Food and Agriculture Organization of the United Nations/ Intergovernmental } \\
\text { Oceanographic Commission of UNESCO/World Health Organization }\end{array}$ \\
\hline FFQ & Food frequency questionnaire \\
\hline FINDIET & Finland National FINDIET Study \\
\hline INCA & Enquête Individuelle et Nationale sur les Consommations Alimentaires \\
\hline INN-CA & Nationwide Nutritional Survey of Food Behaviour \\
\hline INRAN-SCAI & Italian National Food Consumption Survey \\
\hline IZZ-FAO & Food and Nutrition Institute - Poland dietary survey \\
\hline MON & Slovakian dietary survey \\
\hline MS & Member state \\
\hline MRI & Max Rubner-Institut \\
\hline NDNS & National Diet and Nutrition Survey \\
\hline NSIFCS & North/South Ireland Food Consumption Survey \\
\hline NUTRICHILD & Bulgarian dietary survey \\
\hline NVS & Nationale Verzehrsstudie \\
\hline $\mathrm{OA}$ & Okadaic acid \\
\hline OJ & Official Journal of the European Union \\
\hline P95 & $95^{\text {th }}$ percentile \\
\hline P97.5 & $97.5^{\text {th }}$ percentile \\
\hline PlTX & Palytoxin \\
\hline PTX & Pectenotoxin \\
\hline RIKSMATEN & Swedish national food survey \\
\hline SISP04 & Individual Food Consumption - the National Survey \\
\hline STX & Saxitoxin \\
\hline UK & The United Kingdom \\
\hline $\mathrm{VCP}$ & Voedselconsumptiepeiling onder jongvolwassenen \\
\hline WG & Working group \\
\hline YTX & Yessotoxin \\
\hline
\end{tabular}

